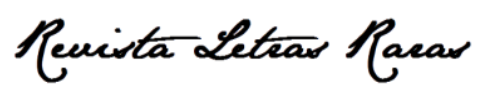

ISSN: 2317-2347 - v. 10, n. 1 (2021)

Todo o conteúdo da RLR está licenciado sob Creative Commons Atribuição 4.0 Internacional

\title{
A natureza da mulher (?): ou do recorte discursivo /
}

\section{The woman's nature (?): or the nature of the discursive selection}

\author{
João Carlos Cattelan* \\ Docente da Graduação em Letras - Unioeste. Docente do PPGL - Unioeste (Mestrado e Doutorado). Mestrado \\ - UFPR. Doutorado pela UNESP - Araraquara. Pós-Doutorado - Universidade de Coimbra \\ iD http://orcid.org/0000-0002-7838-5284
}

Recebido em: 01 ago. 2020. Aprovado em: 10 out. 2020.

\section{Como citar este artigo:}

CATTELAN, João Carlos. A natureza da mulher (?): ou do recorte discursivo. Revista Letras Raras. Campina Grande, v. 10, n. 1, p. 80-96, jan. 2021.

\section{RESUMO}

Busco, com este artigo, atender a dois objetivos construídos contemplados em paralelo. De um lado, tangido por uma celeuma em relação a Michel Foucault no tocante à percepção que ele teria em relação às mulheres, analiso sequências discursivas que mostram a necessidade de considerar a historicidade (local) do discurso, para não atribuir a um autor 0 que não lhe pode ser atribuído. De outro, em face dos recortes selecionados, busco mostrar que muito do que se diz sobre as mulheres tem uma origem datada e que 0 apagamento da historicidade (global) do sentido pode fazer passar por ahistórico, atemporal, universal e natural o que se refere apenas ao nascimento/produção em determinada conjuntura, evitando, assim, fazer passar por natural o que é histórico.

PALAVRAS-CHAVE: Discurso; Mulher; Michel Foucault; Historicidade.

\section{ABSTRACT}

In this paper, I aim at meeting two goals, which will be examined in parallel. On the one hand, touched by a controversy in relation to Michel Foucault's perception of women, I will analyze discursive sequences that unveil the need for considering the (local) historicity of the discourse, in order not to assign to an author what cannot be assigned to him. On the other hand, in view of the selected sequences, I will attempt to show that much of what is said about women has a dated origin and that the erasure of the (global) historicity of meaning may claim as a-historical, timeless, universal and natural what is related only to its birth/production at a certain circumstance, thus avoiding making what is historical seem natural.

KEYWORDS: Discourse; Woman; Michel Foucault; Historicity.

(1)

icc.cattelan@gmail.com 


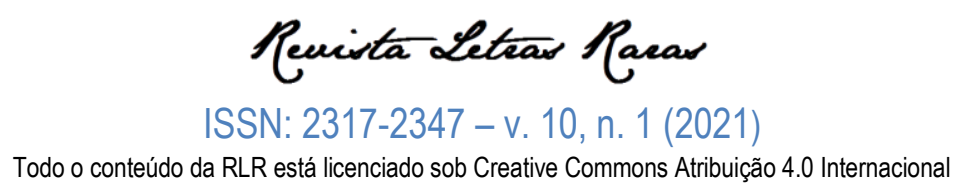

\section{Introdução}

Em aula na pós-graduação, numa conversa sobre lugar e posição, conceitos da Análise do Discurso de linha francesa, um aluno, ao tratar da condição da mulher, recorreu a Foucault para defender a tese de que homens e mulheres são predispostos para algumas atividades, devendo, pois, cada um se restringir ao que the cabe. Manifestei meu estranhamento, pois, do pouco que conheço daquele autor, ele não parece autorizar a leitura apresentada. $O$ aluno foi incisivo em sua defesa, reportou-se à História da Sexualidade 2 (1994) e retirou dela a seguinte citação para sustentar seu ponto de vista: "a natureza dotou a mulher de uma ternura particular para se ocupar dos filhos", o que pode ser encontrado na página 143. Como eu não tinha lido a trilogia, tive que, não sem polêmica, afirmar que voltaria à questão; não voltei, a disciplina terminou e o debate ficou em suspenso.

Volto a esta polêmica, porque, lido a obra em que 0 aluno sustentou a sua argumentação, percebo que fiz bem em não aceitar o fio de sentido proposto no que tange ao que Foucault haveria defendido; há discursos correntes que assumem o primado da natureza da mulher para alguns afetos e eventos, mas não é o que se pode imputar ao autor em relação ao enunciado destacado, recortado, posto entre aspas ou citado pelo aluno. 0 corte feito no tecido textual de suporte da defesa apaga 0 que antecede e o que sucede o fragmento e falha por desconsiderar o todo da obra mencionada.

No caso do excerto, linhas antes, Foucault explicita que está tratando da Econômica de Xenofonte (p. 137), que "esse texto (...) é bem discreto sobre a questão das relações sexuais" (p. 143) no matrimônio e que ela "indica que a natureza dotou a mulher" (grifo meu), em que sobressai (ou deveria ser considerada) a marca de citação de um discurso por outro: "indica"; quanto mais, porque vem acrescida do marcador "também", que remonta ao uso já feito do mesmo ingrediente de atribuição, tornando a operação saliente. No caso do excerto, o marcador de discurso citado está próximo e não deveria passar despercebido: trata-se de uma questão de leitura que demanda um certo comprometimento com o projeto de sentido, quer seja aquele que preside o todo da obra, ou aquele que remete às construções mais pontuais.

Dada a celeuma descrita, fui instado a ler a obra e percebi que, nela, há passagens em que não há marca de distanciamento, como é o caso de "indica". Há excertos em que o discurso do outro aparece apresentado como próprio e o intervalo é subsumido pelo pressuposto de que o leitor deve perceber o que vem do autor e o que vem do discurso objeto, ainda que o seja pelo alerta de que "Os 


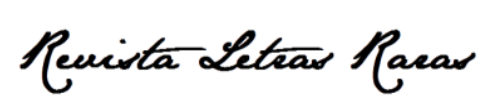

ISSN: 2317-2347 - v. 10, n. 1 (2021)

Todo o conteúdo da RLR está licenciado sob Creative Commons Atribuição 4.0 Internacional

estudos que se seguem, assim como outros que anteriormente empreendi, são estudos de 'história' pelos campos de que tratam e pelas referências que assumem" (p. 13). O problema, assim, é: se, com marca de relato de discurso, o leitor pode cortar uma passagem à revelia e pretender que o efeito seja um, quanto mais isso pode ocorrer em excetos cujas marcas de relato inexistem. E não se trata de recriminar 0 autor por exigir este jogo, mas de fazer com que o leitor o perceba e saiba lidar com ele.

É sobre essa problemática que construo este estudo e a relaciono a uma questão pontual que existe na obra: a concepção de mulher. Há diversas passagens que a tomam como foco e, sem 0 cuidado mencionado, pode-se atribuir ao texto o que não suporta. E não estou em defesa do autor; apenas trato de um problema relativo à citação do discurso. E, em face de a mulher poder, pelo retorno de um discurso retrógrado, sucumbir frente a uma mentalidade reacionária, que diz recuperar a sua "natureza particular", este estudo adquire uma dimensão pragmática, o que não me parece inadequado. Voltando ao ponto: entendo que Foucault discordaria do seu uso por algum discurso machista de tocaia. Desejo que o viés mais político do segundo objetivo não assombre a cientificidade das duas metas que persigo.

\section{Da ambientação do objeto}

A obra de Foucault solicitada como sustentação para a defesa da tese do aluno, na seção Modificações, traz alertas que deveriam nortear o leitor no trajeto. $O$ autor afirma que se afasta da teorização sobre a sexualidade como invariante, cujas manifestações historicamente singulares seriam devidas aos "efeitos dos mecanismos diversos de repressão" (p. 10), e que aborda a temática "como uma experiência historicamente singular" (p. 10 - grifo meu). Ele também assume que o volume 2 "é dedicado à maneira pela qual a atividade sexual foi problematizada pelos filósofos e pelos médicos na cultura grega clássica, no século IV a. C" (p. 16 - grifos meus). Dentre outras, estas são passagens que constrangem o percurso e, na melhor das hipóteses, o leitor pode afirmar que não concorda com a perspectiva grega, mas não pode defender que Foucault pensa como os gregos pensavam; isto até pode ser possível (creio que não), mas o filósofo francês não o assume um momento sequer.

Há, pois, uma tripla historicidade que rarefaz a leitura: ela preside 0 alinhavo das partes constituintes da obra; ela a atrela a um momento da história dos anos 90, quando Foucault a escreveu; 


\section{Penista Letras Pacar \\ ISSN: 2317-2347 - v. 10, n. 1 (2021) \\ Todo o conteúdo da RLR está licenciado sob Creative Commons Atribuição 4.0 Internacional}

ela a remete para uma experiência histórica da sexualidade. Eis uma tripla constrição que impede a atribuição de fragmentos do discurso a quem se deseje, desconsiderando os eixos que a ancoram. É porque o discurso trata de uma prática sexual, é porque o autor, de algum modo, preside a construção do percurso, mas é, talvez, sobretudo, porque, de acordo com Eco (1993, p. 28), "as palavras trazidas pelo autor são um conjunto um tanto embaraçoso de evidências materiais que o leitor não pode deixar passar em silêncio, nem em barulho", que ele não pode construir sentidos à revelia. Sem que se torne uma marionete nas mãos do autor, o leitor também não pode se desvencilhar comodamente do cordame que o orienta e induz.

De modo muito sumário: 0 Uso dos Prazeres possui cinco capítulos, todos destinados a destrinchar o modo como os aphrodisia foram objeto de preocupação moral por parte dos gregos, por meio da reflexão não sobre o ato sexual, o prazer propiciado ou o desejo de usufruto, mas pelo liame que os une; eles poderiam, liberados da sobriedade, da temperança e do domínio pessoal, ocasionar a destemperança, o opróbrio público e a desqualificação para a cidadania em face da inaptidão para o cuidado de si. Foucault mostra, desse modo, que os gregos organizaram uma ética (uma moral), uma dietética (os regimes), uma economia (o cuidado do oikos), uma erótica (o amor pelos rapazes) e uma reflexão sobre o verdadeiro amor, circunstanciado a partir de um ascetismo deliberado. E esse movimento teria uma teleologia: a sabedoria, a verdade e a liberdade (sophrosune), obtidas pelo controle de si e pelo regramento da prática sexual.

É, sobremaneira, no capítulo III, a Econômica, que Foucault, baseado em Xenofonte, traz à tona a relação entre homem e mulher, já que a obra do filósofo "contém o tratado de vida matrimonial mais desenvolvido que a Grécia clássica nos deixou. O texto se apresenta como um conjunto de preceitos relativos à maneira de governar o próprio patrimônio" (p. 137). É neste contexto que surge a mulher, é em relação ao cuidado de si que ela é tematizada e é por referência à propriedade que 0 homem deve atentar para ela como componente do oikos, que "comporta as terras e os bens" (p. 138); a ela cumpre, conduzida pelo marido, ser "associada no governo da casa" (p. 139). Assim, "A arte doméstica é da mesma natureza que a arte política ou a arte militar, pelo menos na medida em que se trata, tanto lá como aqui, de governar os outros" (p. 139). Ressalto: estes são, segundo Foucault, os pressupostos gerais sobre os quais os gregos do período se sustentavam, sendo a mulher pensada, "no quadro do oikos, como um aspecto da responsabilidade governamental do marido" (p. 140). 


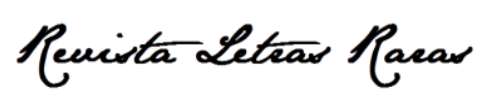

ISSN: 2317-2347 - v. 10, n. 1 (2021)

Todo o conteúdo da RLR está licenciado sob Creative Commons Atribuição 4.0 Internacional

Este conjunto de parâmetros, apresentados brevemente, delineiam a ambientação geral da pesquisa de Foucault, sendo o fio determinante de orientação para o movimento do leitor e que afeta, inclusive, os fragmentos onde nenhuma marca de discurso relatado é utilizada, como por exemplo: "A temperança do marido diz respeito a uma arte de governar, de se governar, e de governar uma esposa que é preciso conduzir e respeitar ao mesmo tempo, pois ela é, diante do marido, a dona obediente da casa" (p. 148), onde é preciso considerar os recursos linguísticos implícitos de atribuição de discurso, como segundo (de acordo com/conforme/para) os gregos; aqueles reportados no texto, é preciso perceber. A presença implícita destes constritores conduz, assim, a reflexão para a problemática da historicidade do discurso.

\section{Da historicidade: um exemplo}

Qualquer evento de linguagem serviria para demonstrar a constitutividade do discurso e das suas condições de aparecimento: dito de uma forma ainda imprecisa, pela historicidade, conceito abrangente que reúne vários traços de aplicação; trato dele na próxima seção. Aqui, mantendo o olhar sobre a obra de Foucault, trago um caso comentado pelo autor, o que garante, por um lado, a aproximação intuitiva da relação inextricável entre o discurso e o seu exterior e, por outro, um dado apresentado por uma voz de autoridade, que confere maior autenticidade a este estudo. Trata-se do aforismo de Demóstenes, que o teria proferido no final do libelo Contra Nera: "As cortesãs, nós as temos para o prazer; as concubinas, para os cuidados de todo o dia; as esposas, para ter uma descendência legítima e um fiel guardiã do lar'” (p. 129).

Lido apartado do contexto de surgimento, o enunciado parece seccionar o mundo em três campos excludentes, incumbindo as cortesãs pelo prazer dos homens (o que não procede, dada a Erótica produzida em relação ao amor pelos rapazes), delegando às concubinas os afazeres cotidianos (o que também não procede, pois as esposas eram também encarregadas do cuidado interno do oikos) e atribuindo a estas a incumbência de terem os filhos e constituírem uma família. De toda sorte, o aforismo parece constituir uma previsão legal ou moral de que o papel da mulher estaria ligado à descendência, sendo-lhe vedado o prazer. Nos termos do próprio Foucault, o enunciado "foi 


\section{Reuista Letras Parar \\ ISSN: 2317-2347 - v. 10, n. 1 (2021) \\ Todo o conteúdo da RLR está licenciado sob Creative Commons Atribuição 4.0 Internacional}

algumas vezes lido como uma tripartição que implicaria funções excludentes: prazer sexual de um lado, vida cotidiana de outro, e enfim, para a esposa somente a continuação da linhagem" (p. 134).

A reflexão de Foucault torna possível sustentar que a visada machista que passou a ser imputada ao excerto se deve mais ao recorte efetuado por quem o utilizou, retirando-o da tessitura geral, do que ao caráter discriminatório e sectário que lhe foi atribuído; o machismo percebido parece estar mais nos olhos de quem o detecta do que daquele que o verbalizou, sendo marcado mais pela constatação positiva de um comportamento cultural do que pela segregação valorativa de diferentes lugares femininos. Penso que a reflexão de Foucault equaciona a problemática relativa ao deslocamento de sentido a que o discurso foi submetido. Para ele,

é preciso levar em conta o contexto no qual essa sentença, aparentemente brutal, foi formulada. Tratava-se de um litigante que pretendia invalidar o casamento aparentemente legítimo de um de seus inimigos, assim como o reconhecimento, enquanto cidadãos, dos filhos nascidos desse casamento; e os argumentos apresentados se baseavam na origem da mulher, seu passado como prostituta, e seu status atual, que não poderia ser outro que não o de concubina. O ponto não era, portanto, o de mostrar que se vai buscar prazeres em outro lugar que não junto à esposa legítima; mas que uma descendência legítima não poderia ser obtida a não ser com a própria esposa. (p. 134 - grifo do autor).

Mesmo que com alguma polêmica, uma vez considerada a constituição da historicidade do discurso, pode-se defender que a alegação do impedimento do trânsito da prostituta para o lugar da mulher de família parece ser inoportuna, que dirá de o prazer pode ser atendido somente pela cortesã. O aforismo, considerado o seu contexto, parece impedir a leitura machista que lhe foi imputada, tendo algo de inovador, inclusive, se for considerado que a argumentação sustenta também um fio que postula que, se as esposas eram tidas para "uma descendência legítima" e se a mulher em questão tinha sido recebida como esposa, mesmo tendo sido prostituta antes e tinha gerado filhos legítimos, estes deveriam ser reconhecidos como cidadãos em virtude do status atual da mãe. Há, na sentença de Demóstenes, assim, um preceito que não coaduna com o embasamento machista e discriminatório, cuja previsão determina que a cortesã deva morrer junto com o filho que está no seu ventre. 


\section{Penista Letraw parar}

ISSN: 2317-2347 - v. 10, n. 1 (2021)

Todo o conteúdo da RLR está licenciado sob Creative Commons Atribuição 4.0 Internacional

\section{Do conceito de historicidade: focos múltiplos}

Esta seção se sustenta no fato de que uma palavra/expressão/enunciado ou fragmento de discurso, e o discurso como um todo, se abstraídos das suas condições históricas de produção, perdem o efeito de sentido primeiro e podem, no limite, migrar para outra esfera de significação. Colocado em outros termos, o discurso é constitutivamente margeado pelo que o circunscreve e pelas relações que tece com o exterior, ou seja, pela sua historicidade, conceito que, a julgar pelos usos feitos, recobre um espectro cujas nuances compreendem desde o entorno linguístico até a história de longa duração. Vou recobri-los de uma forma breve, para optar por uma determinada perspectiva.

Uma das formas de tratar da dependência do discurso em relação ao entorno "histórico" pode ser encontrada em Pêcheux (1995), quando o autor se refere ao intradiscurso, com isso, abordando os fenômenos de co-referência no tecido textual, isto é, aquilo que foi dito antes e será dito depois. Às vezes, esse escopo é designado como co-texto, sendo um dos componentes da historicidade do discurso, dado que o situa num eixo de relações que não pode ser olvidado. Mais difícil de perceber em discursos breves, construções longas como os romances ou a obra citada de Foucault mostram a amarração entre as partes constituintes, tecendo uma dependência em que todo e parte são solidários. Este fenômeno ocorre sempre, mas, talvez, em discursos maiores, torne-se mais perceptível. Em outros termos: há uma historicidade, ou um encadeamento "narrativo", que organiza um antes e depois que não pode ser ignorado. Por reste caminho, chega-se, inclusive, a postular que o discurso cria as suas condições de produção, no sentido de que ou se reporta a um mundo autorreferido ou de que (re)constrói a exterioridade de uma determinada maneira, mostrando-a e a elucidando.

Uma segunda nuance relativa à historicidade do discurso diz respeito ao seu atrelamento ao contexto mais imediato de ocorrência ou à situação comunicativa. Nas suas teses iniciais, Pêcheux (1993), pautado na defesa das formações imaginárias como elementos determinantes dos pontos $\mathrm{Ae}$ $B$, tendo sido criticado por assumir a perspectiva psicologizante que criticava, tratava da determinação dos processos de significação em face da dependência de quem eram os sujeitos envolvidos no processo de produção do discurso sobre determinado referente. Se a crítica é justa ou não, não é significativo aqui, mas não é possivel apagar da reflexão do autor que o sentido do discurso tem uma relação estreita com os sujeitos envolvidos na co-produção do tema que abordam. Eis uma concepção 


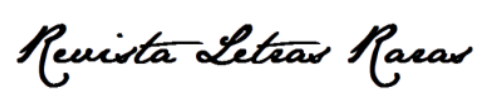

ISSN: 2317-2347 - v. 10, n. 1 (2021)

Todo o conteúdo da RLR está licenciado sob Creative Commons Atribuição 4.0 Internacional

de historicidade que impede que o acontecimento linguístico seja abstraído do seu contexto de ocorrência, às vezes, percebido como constituído de um modo mais empírico e experiencial.

Há, ainda, uma terceira problematização que leva em conta a exterioridade do discurso como ingrediente, condicionador neste caso, dos processos de significação; aqui, fala-se de condições de produção propriamente ditas. Constituídas ideologicamente, seriam, de acordo com Pêcheux (1993, 1995, 2011), as responsáveis pela interpelação dos indivíduos em sujeitos. Então, o discurso não depende do falante empírico que o produz, já que ele é sempre-já sujeito rarefeito pela ideologia e determinado a produzir o discurso de uma forma, sendo subjetivado sobre o quê e como dizer. Os espaços ocupados por A e B são vistos como lugares e posições e o discurso é resultado do interdiscurso que o assombra à distância e de modo determinante. Trata-se, assim, de condições de produção no sentido mesmo de assujeitamento do enunciador, que deve se portar ao sabor do discurso de que é porta-voz. Às vezes, designa-se esta nuance, conforme Orlandi (1999) e Mazière (2007), de contexto em sentido lato. Seja, pois, remetida ao co-texto, à situação comunicativa ou às condições de produção, de caráter mais linguístico ou estruturada pelo exterior, a historicidade do discurso é dada como constituinte.

Contudo, há uma quarta dimensão da historicidade que, sem recusar as três primeiras, porque não haveria fundamento para fazê-lo, afeta o discurso, desta feita, em relação ao sentido produzido. Se o discurso é histórico (e ideológico, por consequência), é porque não funciona ao modo da descoberta da natureza das coisas, mas porque as contorna movido pelo imaginário que as açambarca; ele não diz o que a coisa é, mas o que se imagina seja. E, se o discurso, de acordo com Pêcheux (1993, p. 82), é um "efeito de sentido entre os pontos A e B", não é porque este efeito se constitui ad hoc por meio de movimentos subjetivos, mas porque ele é o espaço preferencial de construção do sentido, que o habita e o condiciona, às vezes, tangido por convicções que travessam as consciências e os tempos, criando um tecido de "evidências".

Para Pêcheux (1993, 1995, 2011), o movimento parafrástico que faz o discurso repetir produz um efeito de transparência, fazendo crer que o sentido só pode ser um e não outro. A coincidência entre um eu que diz que $x$ é $x$ e um tu que concorda que $x$ é mesmo $x$ ocorre, porque tudo se passa no diapasão da conivência, da cumplicidade e da identificação, o que gera a impressão de literalidade, que transcende 0 acontecimento pontual e, no limite, conta com o dicionário para a imposição do sentido "verdadeiro". A assunção de que as coisas só podem ser de um modo, porque sempre foram 


\section{Penista Letear Pacar}

ISSN: 2317-2347 - v. 10, n. 1 (2021)

Todo o conteúdo da RLR está licenciado sob Creative Commons Atribuição 4.0 Internacional

assim, obriga o sentido a se dobrar ao "acordo", sustentado pela repetição, que redunda na reprodução e na defesa da transparência. Perdido o momento fundante da constituição, o sentido parece ser de um modo porque esse é o seu modo. Neste caso, se há uma historicidade do discurso, ela se refere, sobretudo, à historicidade afetada pelo tempo de constituição do sentido que se repete por meio da retomada. Como afirma Orlandi (1999, p. 45 - grifos meus), "A evidência do sentido, que, na realidade é um efeito ideológico, não nos deixa perceber seu caráter material, a historicidade de sua construção".

Para tornar menos abstrata a reflexão sobre a historicidade do discurso/sentido na quarta nuance do conceito, considero uma sequência da obra de Foucault, que não apresenta marcas de discurso relatado, mas não permite compreender que o sentido seja postulado por ele ou que esse sentido pressuponha "a existência evidente dos objetos a saber" (PÊCHEUX, 2011, p. 152): "mas existe, entretanto, algo que, na situação da mulher casada, demanda da parte do marido comedimento e limitação; trata-se justamente da sua posição de fraqueza que a submete à vontade do marido, como uma suplicante arrebatada de sua casa de origem" (p. 160).

Abstraída do co-texto/contexto/condições de produção/historicidade, a sequência induz à conclusão de que a temperança do marido deveria acontecer, mesmo que com "comedimento e limitação", em virtude de a "mulher (ser) casada", de estar numa "posição de fraqueza", que "a submete à vontade do marido", e de ser uma "suplicante arrebatada de sua casa de origem". Porém, mesmo que a sequência não tenha marcas de discurso relatado, considerado o co-texto da obra já mencionado, o contexto de Foucault, como autor, e as condições históricas da década de 90 impedem que o filósofo seja reivindicado como voz de autoridade para sustentar a suposta debilidade da mulher em estreita dependência do esposo, cuja vontade deveria ser atendida. Sobretudo, a historicidade de constituição do sentido, que remonta aos gregos do momento pesquisado, faz ver que o sentido possui uma datação, o que inibe a conclusão de que seja da natureza da mulher o que se diz que é e que é repetido atualmente em discursos caracterizados, não sem razão, como conservadores, já que se postam contra a movimentação e a favor da repetição de concepções que não são evidentes e cuja constituição pode ser datada numa historicidade, neste caso, bastante precisa.

Em suma: a quadrimensionalidade da historicidade (ou, se for o caso, a sua compreensão conforme a quarta perspectiva descrita), que localiza o discurso em ancoragens relativamente precisas, impede a leitura à revelia e a afirmação de que o sentido pertence a quem enuncia, em geral, fazendo perceber que o que se pensa foi forjado em outro tempo, passou pelo crivo da relação de 


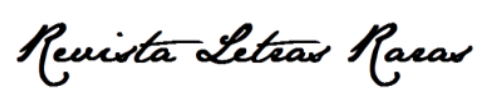

ISSN: 2317-2347 - v. 10, n. 1 (2021)

Todo o conteúdo da RLR está licenciado sob Creative Commons Atribuição 4.0 Internacional

forças (às vezes, de forma violenta) e logrou se implantar como verdade límpida e transparente: pura literalidade cristalina. É na sua quádrupla dimensionalidade, sobretudo no último aspecto, que a historicidade do discurso, potencialmente libertadora, pode vir a ser uma forma de esquadrinhar 0 mundo em que se está imerso e submetê-lo à crítica necessária.

\section{Da análise do objeto: objetivos}

Foucault divide a Econômica de Xenofonte, que contém o tratado de vida matrimonial, em três partes: A Sabedoria do Casamento, A Casa de Isômaco e Três Políticas da Temperança. Das duas últimas, retiro sequências (uma da segunda e três da terceira) para o desenvolvimento desta parte do estudo, não porque são as únicas, mas porque permitem alcançar de modo mais flagrante os objetivos deste trabalho. Em a casa de Isômaco, dada como o modelo desejável de governo e de organização do oikos, pode-se ler:

Fora haverá, portanto, o homem que semeia, cultiva, labora e cria o gado; ele traz para casa o que produziu, ganhou ou trocou; dentro, a mulher recebe, conserva e atribui na medida das necessidades. 'É a atividade do marido que geralmente faz entrar os bens na casa; mas é a gestão da mulher que, o mais frequentemente, regula seu gasto'" (p. 141).

Na casa de Isômaco, a modelagem da conjugalidade e da temperança é contrastada por um dentro e um fora, por um interior e um exterior da casa propriamente dita. À interioridade do ambiente, destinado à mulher por ser uma suplicante fraca, estaria atribuída a regulagem dos bens da família, por meio do recebimento, da conservação e da sua destinação. Trata-se de uma gestão da propriedade doméstica que objetiva evitar o gasto esbanjador do que foi levado para a casa pelo marido. Esta previsão fixa o destino da mulher ao lar que a abriga, inclusive, da violência e do assédio. Em contrapartida, o homem exemplar pertence ao "pequeno mundo dos proprietários de terra que têm que manter, fazer crescer e transmitir para aqueles que têm o seu nome, os bens da família" (FOUCAULT, 1984, p. 137). A ele pertence o exterior da vida do oikos e a atividade de provisão, por meio do trabalho de cultivo, criação de animais e negócios. Com a previsão de que ele é que "faz entrar os bens em casa", assim como em relação à mulher, sela-se uma previsão ideológica. Do lado 


\section{Penista Letras Paras}

ISSN: 2317-2347 - v. 10, n. 1 (2021)

Todo o conteúdo da RLR está licenciado sob Creative Commons Atribuição 4.0 Internacional

dele, encontram-se a coleta, a provisão e a quantidade; do lado dela, acham-se o recebimento, a previsão e a qualidade. Em que pese a aparência de complementaridade que a profecia parece determinar, a mulher está destinada ao lar, em face da fraqueza natural que a constitui.

Percebe-se, portanto, que a pura parafrasagem da sequência destacada (re)alinhava um discurso que coaduna com as teses que têm habitado o pronunciamento de alguns personagens atuais e, assim, o fragmento de Foucault, descolado de sua historicidade, sugere a anuência com discursos sectários. Na medida em que estendi o comentário sobre o excerto, transformando-o em palavras próprias (sem o uso do condicional), posso ser considerado, se descontextualizado, também como machista, à luz de passagens como "por ser uma suplicante fraca" e "o homem é responsável pela provisão dos bens da família". É exatamente contra esta des-historicização do discurso que este trabalho se constrói, na medida em que o efeito de sentido se constitui pelo interior e pelo exterior e é atravessado por um objetivo que não pode ser ofuscado.

Em outros termos, uma parte de um discurso não pode ser retirada do seu todo (embora 0 seja frequentemente) para atender a propósitos cujas metas não coadunam com a hipótese construída pela obra, que passa a ser lida à revelia. De um lado, acho difícil imputar a Foucault a sequência acima; de outro, parece-me inoportuno atribuir a ele o sentido que a sequência, no seu interior, articula. Mesmo que ela não possua marcas explícitas de atribuição, neste caso, aos gregos, não é por parecer ser pertencente ao autor que o discurso deve ser dado como dele. Esta reflexão me faz pensar na possibilidade de uma distinção entre uma historicidade local e uma global no que tange à ancoragem do discurso. Na primeira, apareceriam o co-texto, o contexto e as condições de produção; na segunda, entraria a constituição do sentido, no que possui de datação histórica, que, às vezes, dirige-o a paragens distantes, as quais, obliteradas, podem criar efeitos de evidência e de natureza. Se, por um lado, em face das três primeiras garantias, não se pode considerar Foucault como machista, por outro, dada a quarta guarida, a concepção de mulher pertence ao mundo grego clássico, que ainda reverbera. Repito: não estou defendendo Foucault, mas considero a obra referida como um dado pertinente para uma ordem de problemas.

A próxima sequência, assim como a anterior, tomada à revelia das circunscrições que a determinam, também poderia, inadvertidamente, ser ligada aos saberes produzidos por Foucault e, desse modo, ser considera como iluminando o mundo em transparência e evidência dada a repetibilidade parafrástica em que se encontra (na obra e no mundo): 


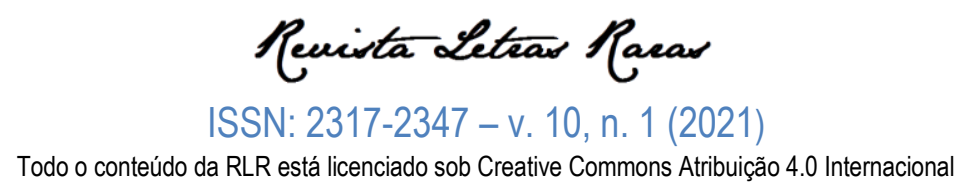

E foi para esse suplemento do melhor-viver que a natureza dispôs, como fez, o homem e a mulher; foi visando a vida comum 'que ela organizou um e outro sexo'. 0 primeiro é forte, o segundo é contido pelo temor; um encontra saúde no movimento, o outro é inclinado a levar uma vida sedentária; um traz os bens para a casa, o outro vela sobre o que aí está; um alimenta os filhos, o outro os educa. A natureza programou, de certa forma, a economia da propriedade doméstica e os papéis que cada um dos esposos deve aí desempenhar (p. 157).

Por meio de paralelismo contrastante, homem e mulher são comparados, colocando, de um lado, a força, o movimento, a produção e a alimentação e, do outro, o temor, o sedentarismo, o cuidado e a educação. Colocados em polos dissimétricos que competem entre si, a mulher seria destinada às atividades domésticas e à educação, dada a sua suposta predisposição para a salvaguarda do interior do oikos, enquanto o homem, em face do destemor e da força, teria, naturalmente, sido disposto para a labuta externa e para os negócios. Este discurso, maniqueísta, não é dificilmente encontrado hoje. Seja, portanto, por uma razão ou outra, os papeis de homens e mulheres seriam irreconciliáveis, dadas as diferenças que, em virtude dos atributos físicos, colocam-nos sob coerções distintas.

Esta sequência apresenta um ingrediente a mais em relação à anterior, quando afirma que as diferenças entre os sexos foram dispostas pela "natureza", objetivando o "melhor-viver" e a "economia da atividade doméstica". Se fosse dessa forma, haveria que se concluir que o que separa homens e mulheres não possui determinação político-ideológica, já que, naturalmente, "um e outro sexo" aconteceram de uma maneira, estabelecendo o papel que "cada um dos esposos deve desempenhar". O efeito de evidência especular e de descrição desapaixonada ganham relevo, aqui, e as luzes da história podem passar despercebidas, fixando a percepção de que é assim, porque a natureza o fez. Aqui, o atravessamento do processo discursivo para chegar ao suposto real do mundo, como é criticado por Pêcheux, parece ganhar relevância e a historicidade do sentido que deve ser imputada aos gregos pode, com desatenção, ser atribuída a Foucault ou remontar à natureza, ofuscando a tessitura grega da imagem de mulher.

Por atribuir a cisão entre os esposos à natureza, que teria equacionado as carências do melhor-viver e da economia doméstica, o leitor pode se apegar à defesa da distinção entre eles, como sendo ocasionadas por uma força externa: o que está longe de inexistir, à vista de alguns discursos. Para isso, contribui o fato de que a sequência pode (não deve, mas pode) ser retirada do local de aparecimento, produzindo um efeito de autonomia e autenticidade: decalque do mundo; atividade 


\section{Penista Letras Pacar \\ ISSN: 2317-2347 - v. 10, n. 1 (2021) \\ Todo o conteúdo da RLR está licenciado sob Creative Commons Atribuição 4.0 Internacional}

inaceitável, ela possui uma historicidade (co-texto, contexto e condições de produção) e atesta outra, a do sentido, pois nem é certo que homem e mulher sejam concebidos como na passagem e tampouco que a natureza os tenha disposto para dentro ou para fora de casa. Cabe ao leitor recuperar as marcas implícitas de discurso relatado, para que o excerto seja posto no eixo de ancoragem mais oportuno.

Destaco outra sequência que, por ausência de marcas de discurso relatado, pode ser, de modo inoportuno, atribuída ao autor, se abstraída da sua historicidade geral, e pode ser pleiteada como tendo um sentido evidente e especular, em virtude das similitudes que a açambarcam:

Não se dá o mesmo com a mulher: sem dúvida esta é e será sempre inferior ao homem, e a justiça que deve reger as relações entre os esposos não pode ser a mesma que reina entre os cidadãos; contudo, por causa de sua semelhança, o homem e a mulher devem ter uma relação que 'se aproxime muito da justiça política' (p. 159).

Partindo da hipótese de que, para os gregos, "o homem deve guardar a superioridade permanentemente" (p. 159), a sequência produz a derivação de que, entre o homem e a mulher, não pode haver uma relação de simetria, uma vez que, "sem dúvida", ela "será sempre inferior ao homem" (grifo meu). O marcador temporal "sempre", que, no limite, ancora a defesa da imutabilidade em face da suposta determinação natural de constituição do objeto, pode, assim, induzir que a diferença se faz ad eternum e que ela não permite uma justiça que seja igual para ambos, pois ela "não pode ser a mesma que reina entre os cidadãos". Apesar da analogia com o vínculo político da administração das cidades, a relação entre os esposos é dada como perene, enquanto, lá, ela é cambiante. Em face da natureza da mulher, que a fez débil e temerosa, uma suplicante, entre os esposos, há "uma relação que se aproxima muito da justiça política", que impediria a coincidência igualitária entre eles, já que a mulher "sempre" estará numa relação de inferioridade ao homem, dados a sua força e destemor.

Apagada a historicidade local de constituição, a sequência, abstraída do acontecimento que a ocasionou, poderia ser imputada a Foucault, por causa da ausência de marcas de discurso relatado, e poderia ser considerada como remetendo à ontologia natural da mulher, já que seria para "sempre" o que "sempre" foi. E, por isso, a relação entre os dois pode se aproximar da justiça, até "muito", se for o caso, mas sem perder a dissimetria natural que a caracterizaria. Além disso, se apagada a historicidade global da sequência, que a escrutina em relação aos seus ditames ideológicos, pode-se crer que ela retoma, como dito, um sentido evidente e natural, neste caso, sobremaneira, deixando de 


\section{Penista Letras Paras \\ ISSN: 2317-2347 - v. 10, n. 1 (2021) \\ Todo o conteúdo da RLR está licenciado sob Creative Commons Atribuição 4.0 Internacional}

perceber o seu nascimento num ponto mais ou menos preciso do tempo (o que Foucault pesquisa), fazendo-o recuar a uma perenidade forjada pela natureza, que teria plasmado o homem e a mulher para atender a necessidade do "melhor-viver". A operação de recorte ou de citação por desconsideração à historicidade pode, por um lado, atribuir um discurso a quem não o defende e pode, mesmo frente a uma ocorrência explícita, não se dar conta de que o sentido é histórico e determinado por forças conjunturais de constrangimento. Mesmo que se tenha dito e ainda se diga que a mulher é de um modo, o que é dito é movido por forças sócio-históricas datadas e, por isso, temporais.

Recorro a uma última sequência para manter as teses de que um fragmento retirado de suas cercanias pode fazer atribuir o que não deveria e levar a assumir que o sentido é natural, quando ele é constituído num momento, mais ou menos, localizável no tempo e no espaço:

se, de fato, a autoridade do marido sobre a mulher é mais fraca, menos total que nas duas primeiras relações (escravos e filhos), ela não tem o caráter simplesmente provisório que se encontra na relação 'política', no sentido estrito do termo, isto é, na relação entre cidadãos livres num Estado; é porque, numa constituição livre, os cidadãos comandam e são comandados alternadamente, enquanto na casa é o homem que deve guardar a superioridade permanentemente (p. 158-159).

Novamente, a pauta do poder do homem e da relação dissimétrica entre os esposos é abordada e, aqui, ela é contrastada com outras relações sob as quais eles se veem tangidos, no oikos ou na vida pública. Diferentemente do Estado, onde o poder é alternado e exige simetria, dada a provisoriedade, em relação aos escravos e aos filhos, ele é mais ou menos abrangente e menos total no caso da mulher, sem que se confunda com a igualdade de poderes decisórios. É devido à alternância do poder que caracteriza uma constituição livre e ao fato de que o comando é alternado que a cidadania simetriza as relações entre os homens, o que não deve ser levado para o governo da casa, onde escravos, filhos e esposa têm, cada um, um grau maior ou menor de submissão. Há uma hierarquização das relações de obediência, devendo o escravo estar numa posição de diferenciação máxima, enquanto a cidadania pressupõe o mais alto grau de simetria. Os filhos e a esposa ficam no entremeio da escala, com ela sendo postada num grau de menor submissão à autoridade do marido, cuja superioridade permanente, porém, dá o diapasão.

Voltando ao ponto: a sequência, dado o seu efeito de aparente completude e autonomia, permite, em face da menor contenção do leitor, ser o atestado de uma tese, dado o suposto discurso 


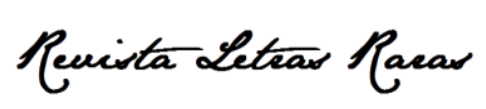

ISSN: 2317-2347 - v. 10, n. 1 (2021)

Todo o conteúdo da RLR está licenciado sob Creative Commons Atribuição 4.0 Internacional

de autoridade de que ela seria o suporte. Como não possui marcas de discurso relatado (segundo, conforme, de acordo com, para, neste caso, os gregos), a abstração da historicidade local pode levar o leitor a fazer dela um sintoma do machismo ou a constatação de obra da natureza sabia, impondo um sentido que não resiste ao escrutínio e postulando uma delegação de vozes que não se sustenta. Se retorno à discussão com o aluno, devo concluir que a atividade dele só pode ocorrer por meio do apagamento das bordas que circunscrevem a passagem (mal) usada Além disso, a historicidade do sentido que atravessa a sequência não permite que a nuance ideológica da relação matrimonial que se estabelece nela seja imputável ao autor, apagando as rarefações globais estabelecidas, e nem que ela remete à natureza, o que é impedido pela relação com o matrimônio e com a política, instituições que remontam, sobretudo a segunda, ao mundo grego. O sentido é um construto histórico e ideológico que tem uma datação e é cambiante, podendo vir a ser outro, mas também, em face de forças conservadoras movidas por determinados interesses, permanecer o mesmo, tornando-se "evidente".

\section{Considerações finais}

Retomo os objetivos deste trabalho: com um deles, eu buscava demonstrar que, às vezes, 0 recorte de um fragmento de discurso, em face de determinados propósitos, é efetuado de modo a fazê-lo servir a uma meta para a qual definitivamente não concorre. Neste caso, a sequência, por possuir uma certa completude e inteireza e não apresentar marcas de discurso relatado, pode ser imputada a quem não deve e ser tomada como voz de autoridade para sustentar um discurso com 0 qual não coaduna. Dessa maneira, co-texto, contexto e condições de produção, o que designei como historicidade local, são imprescindíveis para a caução do efeito de sentido. 0 ganho com este cuidado, necessário, estaria, sob o meu ponto de vista, no fato de agir com uma certa honestidade intelectual, o que me parece sempre desejável.

Com o outro, busquei refletir sobre o fato de que o sentido, geralmente (se não sempre), no que é uma matriz ideológica, retoma discursos prévios produzidos numa conjuntura que, despercebida, pode levar o leitor a assumir um efeito de evidência, de naturalidade, de isomorfia e de especularidade que, entretanto, nada tem de a-histórico, atemporal e universal e deve ser inquirido sobre o seu momento de constituição e sobre as constrições que o afetavam, para perceber que, às 


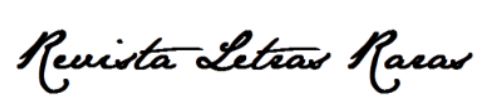

ISSN: 2317-2347 - v. 10, n. 1 (2021)

Todo o conteúdo da RLR está licenciado sob Creative Commons Atribuição 4.0 Internacional

vezes, o que se diz pertence a outras coerções e que o aproveitamento sem essa percepção pode levar a repetir o que não se sustenta, caindo num conservadorismo esclerosado e num dogmatismo autoritário que não evolui, submetendo o mundo a correntes.

Percebo agora que o outro fio que atravessa a tessitura deste texto, talvez, tenha me cooptado sem eu perceber: trata-se de as sequências terem como fio de reflexão a relação matrimonial e, sobretudo, a entrada da mulher como tema da escrita. Percebo que as teses presentes nos excertos, embora pensadas há milênios, continuam postuladas por alguns discursos, com a reiteração de afirmações que não se sustentam no Século XXI em face dos avanços conquistados pelos movimentos femininos e pela sociedade em geral. Elas ainda são o simulacro que orienta discursos designados como conservadores, com justiça, porque, à luz das passagens analisadas, eles reeditam crenças antigas, forjadas ao sabor de um tempo agrícola e escravocrata; e continuam assombrando determinadas mentes, de não pouca importância, que afirmam, como o fez o "novo" ministro da Educação, que "o homem, dentro de casa, é o cabeça do lar; ele aponta o caminho". Sempre acho pertinente ouvir Bourdieu (1999, p. 100 - grifos do autor) sobre questões como essas: "é preciso reconstruir a história do trabalho histórico de des-historicização, ou, se assim preferirem, a história de (re)criação continuada das estruturas objetivas e subjetivas da dominação masculina".

\section{Referências}

BOURDIEU, Pierre. A dominação masculina. (Trad. Maria Helena Kühner). Rio de Janeiro: Bertrand Brasil, 1999.

ECO, Umberto. Interpretação e superinterpretação. (Trad. MF). 3.ed. São Paulo: Martins Fontes, 2001. FOUCAULT, Michel. História da sexualidade 2: o uso dos prazeres. (Trad. Maria Thereza da Costa Albuquerque - Rev. Técnica José Augusto Guilhon Albuquerque). 7.ed. Rio de Janeiro: Edições Graal, 1994.

MAZIĖRE, Francine. A análise do discurso: história e práticas. (Trad. Marcos Marcionilo). São Paulo: Parábola Editorial, 2007.

ORLANDI, Eni Puccinelli. Análise de discurso: princípios e procedimentos. Campinas, SP: Pontes, 1999. 


\section{Peuista Leteas Pacas}

ISSN: 2317-2347 - v. 10, n. 1 (2021)

Todo o conteúdo da RLR está licenciado sob Creative Commons Atribuição 4.0 Internacional

PÊCHEUX, Michel. Análise Automática do Discurso: atualização e perspectivas. GADET, Françoise \& HAK, Tony. Por uma análise automática do discurso: uma introdução à obra de Michel Pêcheux. (Trad. Bethânia S. Mariani et al.). 2.ed. Campinas, SP: Editora da UNICAMP, 1993.

PÊCHEUX, Michel. Semântica e discurso: uma crítica à afirmação do óbvio. (Trad. Eni Puccinelli Orlandi et al.). 2.ed. Campinas, SP: Editora da Unicamp, 1995.

PÊCHEUX, Michel. Análise do discurso: Michel Pêcheux. Textos selecionados: Eni Puccinelli Orlandi. 2.ed. Campinas, SP: Pontes Editores, 2011. 